\title{
Causes of Delay in Construction of Motorable Bridges under "Design and Build Model" of Bridge Project, Department of Roads, Nepal
}

\author{
Surya Prasad Timilsina1, Sateesh Kumar 0jha1, Bharat Ram Dhungana ${ }^{2}$ \\ ${ }^{1}$ Lincoln University College, Kelantan, Malaysia \\ ${ }^{2}$ Pokhara University, Pokhara, Nepal \\ Email: timisurya@gmail.com
}

How to cite this paper: Timilsina, S. P., Ojha, S. K., \& Dhungana, B. R. (2020). Causes of Delay in Construction of Motorable Bridges under "Design and Build Model" of Bridge Project, Department of Roads, Nepal. Modern Economy, 11, 1451-1462. https://doi.org/10.4236/me.2020.118103

Received: July 1, 2020

Accepted: August 7, 2020

Published: August 10, 2020

Copyright (c) 2020 by author(s) and Scientific Research Publishing Inc. This work is licensed under the Creative Commons Attribution International License (CC BY 4.0).

http://creativecommons.org/licenses/by/4.0/

\begin{abstract}
This paper aims at detecting the causes of delay in the "design and build model" of motorable bridge construction under the Bridge Project, Department of Roads, Nepal. The research is based on an intensive literature review, primary data, secondary data, and interviews. The survey which was carried out with the help of questionnaires was used to assess the perceptions of the respondents involved in the construction of the "design and build model" of the bridge project. The questionnaire was divided into three parts and the main part focused on the causes of delay in "design and build model" in the implementation of such projects. A total of 56 different causes for delay of bridge construction were identified through the literature review and a pilot survey of three groups of respondents who were involved in the construction of such bridges (see literature review of this paper). The eight most important causes, among 56, identified by the study are: 1) Lack of stakeholder analysis 2) Poor portfolio management 3) Lack of inadequate pre-execution planning and improper time management 4) Lack of site management 5) Inadequate budget allocation and delay in payment 6) Lack of provision of reward and penalty, 7) Lack of detail survey, improper soil exploration and preparing report without depth study and 8) contractor's excessive workload. The cost, quality, and schedule of bridge construction projects can be maintained once the problem of unnecessary delay is resolved and the competency of the construction industry in Nepal will improve.
\end{abstract}




\section{Keywords}

Construction Industry, Design and Build Model, Motorable Bridge, Delay

\section{Introduction}

Construction industry serves in many ways: makes magnificent buildings that shine in the city, bridges that connect people from one place to another, roads networks that provide comfort to the citizens and airport terminals that help to connect the different parts of the world. In this way, construction industries are increasing the image of the country in the international arena and increase GDP by providing services to different sectors of productivity. Not making the availability of the construction products means lagging a country back.

Construction is said to be the Delay in construction is considered to be one of the recurring problems in the developing countries and it harms the success of projects in terms of time, cost, and quality. Delays in bridge construction are the most serious problems which can even slow down the national development. It is widely accepted that a project is successful when it is finished on time. Unfortunately, due to many reasons, large numbers of bridge construction projects fail to follow the planned work schedule and are hence delayed. In Nepal, delays in implementation in public sector investment seem to be very common. There are two government projects formed for road and bridge construction in Nepal, namely-Local Road Network (LRN) and Strategic Road Network (SRN) under the Department of Roads (DoR). Bridge Project of DoR introduced the "design and build model" of construction of motorable bridges since fiscal year (FY) 2012/2013. There are about 180 numbers of designs and build motorable bridges under SRN and LRN being implemented until FY 2018/19. 10 bridges out of 30 numbers of bridge project sector-3 under "design and Build" are completed and others are under construction.

Almost all the bridge projects are facing time overrun and have become big challenges to implementing agency the DoR. Generally, there are three types of delay; excusable, non-excusable and concurrent Excusable delay of two categories-first the compensable that are caused by employer or employers' agent and next to the non-compensable that are caused by contractors. Concurrent delays are caused by a third party or incidents that are beyond the control of both employers and contractors.

The objectives of this study are to explore the status of bridge completion rate, to determine the main reason behind delays in construction of bridge under the bridge project in Nepal, and to recommend an amicable solution for minimizing delays in bridge construction projects.

\section{Literature Review}

Many studies have been carried out in the past to determine the causes of delays 
in the construction industry.

Karunakaran, Malek, and Ramli (2019) identify the causes for the significant delay as; poor project planning and scheduling followed by frequent design changes, the existence of many underground utilities, unforeseen additional work, shortage of materials, failure of material and equipment, poor communication and interaction, labor issues, weather, improper construction method, inexperienced contractors and poor site investigation.

Bista and Dahal (2018) conclude that low bidding as the main reason for delay because of a large number of existing variables like unrealistic norms, unrealistic district rates, ambiguities in the contract document, and social acceptance, and these must be minimized. Such variables and performance happen to be inversely proportional to each other in this case. The findings reveal that road projects are prone to cost overruns, they have a very large magnitude of cost overruns and the causes of cost overruns vary for all road projects (Ahmad, Anigbogu, \& Molwus, 2018).

Islam and Trigunarsyah (2017) identify the main reason for the delay as financial issues like; contractor's cash flow problem, and delay in progress payment by the employer, managerial issues such as poor site management, contractor related factors, i.e., improper planning and scheduling, and employer-related factor-like order for design change during construction is the most important and frequent factor that directly forces to delay the work schedule all over the developing world. The delay and cost overrun of infrastructure projects were caused by 20 factors according to the records in the collected final reports of projects. The results showed that Terrain and Weather conditions are the top factors causing completion delay and cost overrun in infrastructure projects in Jordan (Al-Hazim, Salem, \& Ahmad, 2017).

Suwal and Shrestha (2016) find the main causes of delays are unusual low bid by contractors, lack of planned pre-execution of the project, delay in receiving clearances from various government authorities, poor site management and supervision by contractors due to large numbers of works in hand. Saudi Arabia has been facing issues with completing construction projects on time and on budget. They identified nine causes of delays that both studies documented. The study also proposes a solution to minimize the nine major delay factors. A literature research identified one construction management method, the performance information procurement system, has documented multiple times its ability to improve project performance and minimize delays (Alzara, Kashiwagi, Kashiwagi, \& Al-tassan, 2016).

Lokhandwala and Bhatt (2015) find nine key reasons for a delay in the construction area: project-related, owner-related, contractor-related, consultant-related, design-related, material-related, equipment-related, labor-related, and external factors depending on their nature and mode of occurrence. Seboru (2015) identifies the top five causes of delay identified by both consultants and contractors and those were: delayed payment by the employer; slow decision-making and 
bureaucracy in employer's organization; Claims; inadequate planning/scheduling and rain. Nuclear Power Plant (NPP) construction schedule delay risk assessment methodology is developed and the construction delay risk is assessed for turnkey international NPP projects. The study finds the top five most important sub-factors, which are as follows: policy changes, political instability and public intervention; uncompromising regulatory criteria and licensing documents conflicting with existing regulations (Hossen, Kang, \& Kim, 2015).

Shah and Apte (2015) highlight the prominent reasons for the delay are related to contractors' performance such as site management, labor productivity, and lack of expert proficiency in supervision, etc. The client was held responsible for the delay in issuing drawings and design. Timely implementation of construction works (at the scheduled time) is vital for both the investor and the contractor (Gluszak \& Lesniak, 2015). One of the major problems that face the construction projects in general and road projects in specific is being behind the schedule, i.e., delay in submission. Delay can be defined as postponing the project completion time due to predicted and unpredicted causes (Honrao \& Desai, 2015).

Hytiris, Stott, and McInnes (2014) find the site investigation was one of the earliest processes and very essential in any type of construction to execute a project successfully within the cost and timeline. Hasan, Suliman, and Malki (2014) identify many causes of delay related to contractors such as; improper planning and scheduling. One of the major causes related to the employer-Ministry of Works (MoW) was delaying in decision making. The main problem related to consultants was lack of experience. Moreover, cost and time overruns were two of the most frequent adverse impacts of delay.

Gidado and Niazai (2012) opine in the case of Afghanistan-Security, corruption, poor qualification of the contractor's technical staff, payment delays were the main causes of delay in construction projects. Kazaz, Ulubeyli, and Tuncbilekli (2012) conducted a study in Turkey and find changes in design and material were found to be the most predominant factors, followed by a delay of payments. Cash flow problems and managerial issues of time extensions are encountered in developed and developing countries, whereas; financial causes are experienced in developing countries.

Pourrostam and Ismail (2011) identify predominant causes of delay were poor site management and supervision, delay in progress payment by employers, change orders by an employer during construction, ineffective planning and scheduling of project by the contractor, financial difficulties of a contractor, slowness in the decision-making process by an employer, delays in producing design documents, late in reviewing and approving design documents by an employer, poor contract management by consultant and problems with subcontractors.

Haseeb, Lu, Bibi, Dyian, and Rabbani (2011) researched problems of projects and the effects of delays in the construction industry of Pakistan. They found 
that the most common factor of delay is a natural disaster in Pakistan like floods and earthquakes and some others like-financial and payment problems, improper planning, poor site management, insufficient experience, shortage of materials and equipment, etc.

Abdullah, Rahman, and Azis (2010) opined that experience was vital in the construction industry as it comes with valuable knowledge that could not be obtained from other sources. Inexperienced contractors are one of the factors that will create havoc in the time overrun of a construction project.

\section{Research Methodology}

This study reviewed many articles published in various technical journals that explored the causes of delays in construction projects. An interview question was designed for this study to know the reasons for the delay. Available data from the DoR were used to analyze the status of delays in construction of "design and build model" bridges implemented by bridge projects. Approximately 30 consultants and 100 contractors (all categories) are currently working on the design and build a model of bridge construction within the DoR as reported by their officials. Only the first-class contractors, who had 20 years or more experience in bridge construction, were contacted for this interview survey. The survey was conducted among 10 professional consultants, 30 contractors, and 10 concerned government officials. A pilot survey was conducted through interviews with 5 experienced contractors, 3 experienced consultants, and 7 experienced project managers who had 20 years or more experience in the construction of a bridge.

The query made was by the question "Almost all of the projects are delayed, what are the causes for delay in a project in your experience?" Besides, their answers are listed in the data collection section.

\subsection{Reliability and Validity}

Reliability refers to consistency in the answer from the respondents to a question. The responses were verified by repeating by asking the questions again, once the questions and answers with each of the respondents were over.

Validity refers to whether the instrument tested what it ought to measure or not. The test tried to find the causes of delay, which was the objective of this research. Efforts also were made to see whether the respondents understood the intention clearly or not. In case found and doubt that respondents did not understand the question and its intention, efforts were made to make them clear.

\subsection{Data Collection: The Data Regarding Agreement Data, Intended Completion Period, Completion Progress/Date Has Been Presented in Appendix 1 (DoR, 2019)}

The sources of data are primary. The empirical data has been collected with the help of an interview.

\section{Interview of Respondents}




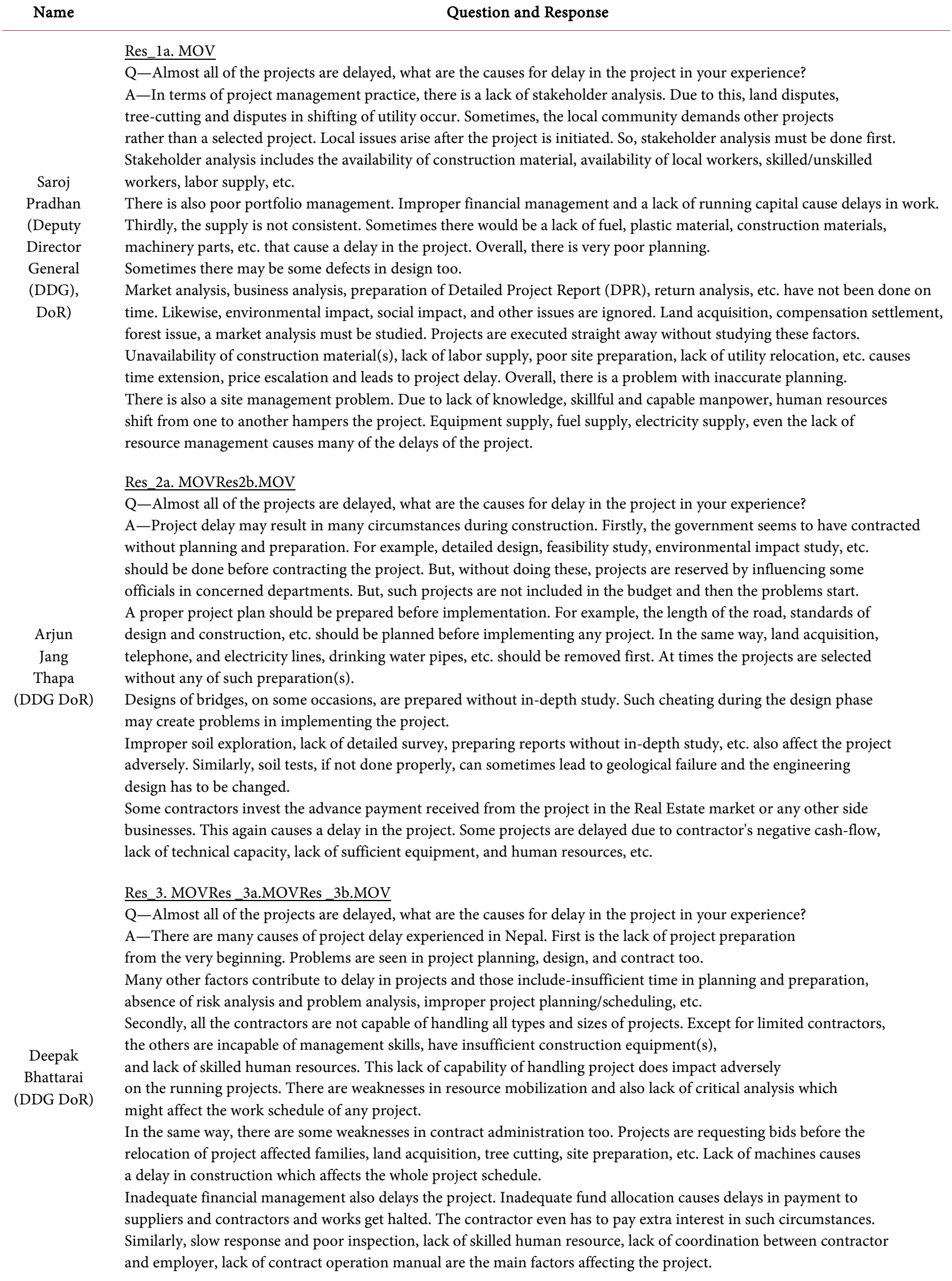




\section{Continued}

Mukti

Gautam

Former

(DDG DoR)

and now a

Consultant

Rabi Singh

(President,

FCAN)

Bishnu

Prasad

Sharma

(MD,

Lumbini

Builders)

Shriram

Maharjan

(Chairman,

ANK

Construction)

Bahadur

Singh Lama

(MD,

Himdung

and Thokar

CO.)

Harinarayan

Rauniyar

(Former MD

Pappu

Construction)
Resp 4a. Movres 4b.MOV

Q-Almost all of the projects are delayed, what are the causes for delay in the project in your experience?

A-There are mainly three partners in the project; employers, consultants, and contractors.

Local people also influence the project. Projects are tendered without prerequisites and hence lack of site

preparation, land acquisition, cutting down the trees, removal of utility in the site area, etc. causes project delay.

Lack of financial resources affects budget allocation, resulting in the fund mobilization for the project.

There are also some technical problems, especially in the bridge construction project.

Res 5. MOV

Q-Almost all of the projects are delayed, what are the causes for delay in the project in your experience?

A-Construction projects are started without any in-depth study and proper planning.

Later, it hampers on project implementation. Some factors like improper detailed survey, lack of coordination

and communication, untimely transfers of project chiefs, and staff also cause project delay.

Ignoring the in-depth study, EIA, land acquisition, etc. causes incompletion of the project.

Inadequate budget allocation and delay in payment also affects the project adversely.

Res 6a. MOVRes 6b.MOV

Q-Almost all of the projects are delayed, what are the causes for delay in the project in your experience?

A-Low bidding, delay of payment, poor management, lack of coordination between government agencies, no site preparation, etc. are the factors that adversely affect the timeline of the project. There is no state policy on the construction sector as well as the development of infrastructure. On the other hand, contractors try to get projects at any cost and they use the advance amount for payment of various debts, payment for employees, etc. The government should make transparent policies about the contract bidding process. The contract should be awarded as per their capacity.

A monitoring body should be set up and the state should also set a benchmark for quality control.

Res 7a. MOV

Q-Almost all of the projects are delayed, what are the causes for delay in bridge project in your experience?

A-The "design and build model" is in the early stages currently. Hence, it seems to be a lack of experience in it.

Lack of in-depth study, improper time management, improper decision making, lack of quick decision, etc. causes a

delay in bridge construction. Similarly, inadequate budget and delay in payment impact in the construction project.

Q-What would be the other reasons for this problem?

A-Lack of provision of reward and penalty based on work performance causes a delay in work. Lack of coordination

between various government agencies, political interference during construction, unforeseeable site conditions, etc.

leads to delay in the project.

Q-How do you explain that some contractors winning more projects through bidding and subletting to other sub-contractors also the main reason for the delay in the project?

A-If they are capable of handling large scale projects, they can do it in a better way. But, if there is a lack of finance, equipment, resources, etc. then they cannot construct large scale projects and that leads towards incompletion of the project.

Rep 8. MOVRep_8a.MOV

Q-Almost all of the projects are delayed, what are the causes for delay in the project in your experience?

A-We are generally experiencing delays in construction projects. First of all, there is a lack of studies and researches in the development sectors. Lack of study on the impact on environment and society, proper design, inadequate finance, a supply of construction materials, lack of unavailability of specified materials, land acquisition are other main factors that affect the construction projects adversely. In the same way, political instability and budget also affect the work.

Construction companies are also liable equally. Lack of in-depth study, inadequate pre-execution planning, improper time management also affects adversely the construction projects in timely completion.

\section{Res 9. MOV}

Q-Almost all of the projects are delayed, what are the causes for such delays in your experience?

A-There are some weaknesses in the construction professionals and some of them are brought about by the rule and law of the state. For example, the government bids for large investment projects but only a small amount of budget is allocated. Due to this inaccuracy of budget and time, the project can't run smoothly.

Similarly, the project is chosen where there are no infrastructures like; road, electricity, etc. The selected project passes through forest area and forest department resists cutting down trees and hence the construction gets halted. Likewise; local people may interrupt and oppose compensation if they are displaced from the project site. There is no restriction forbidding any number of contracts. Due to this legal error, lack of finances as well as delays from contractors,

a construction project will not complete on time. Likewise, a shortage of construction material(s) also affects the work schedule. It happens when raw materials like gravels/pebbles/sand extraction are banned temporarily in the rainy season. Price escalation of material(s) also affects the project adversely. Thus, budget, slow site hand over, availability of raw materials, lack of transparent policy of the government, bureaucratic hurdles and lack of co-ordination/communication among concerned parties are the main reasons that affect the construction project badly. 


\section{Continued}

$\begin{array}{cl}\text { Bashu dev } & \text { Res 10. MOV } \\ \text { Upreti } & \text { Q-Almost all of the projects are delayed, what are the causes for delay in the project in your experience? } \\ \text { (MD Dev } & \text { A-The most prominent problem in the construction field is the site location. Lack of land acquisition, } \\ \text { and Sayer } & \text { slow site hand-over, lack of access road to site area are the main factors in the delay. In the same way, delay in budget } \\ \text { Construction) } & \text { and payment difficulties and time extension of the project also affects adversely to complete any project. }\end{array}$

\section{Discussion}

In terms of project management practice and based on the interviews conducted, the following have been prominently noticed for delays in Bridge project undertaken by DoR in "design and Build Model":

- Lack of stakeholder analysis: Due to this, land disputes, tree cutting, utility Shifting disputes, availability of construction material, availability of local and skilled/unskilled workers, labor supply, etc. have impacted the progress of bridge construction.

- Poor portfolio management: Improper financial management and lack of running capital causes delay in work. Inadequate fund allocation causes delays in payment to suppliers and contractors and halts the work.

- Slow response and poor inspection: lack of skilled human resources, lack of coordination between contractor and employer, lack of contract operation manual are the main factors affecting the project.

- Lack of transparent policy of the government: bureaucratic hurdles and lack of co-ordination/communication among concerned parties are some of the main reasons that affect the construction schedule of the project.

- Lack of detailed analysis: Risk analysis, Market analysis, business analysis, return analysis prepared DPR, etc. have not been done on time. Likewise, environmental impact, social impact, and other issues are ignored. Land acquisition, compensation settlement, forest issues are other factors that have been given less importance, and the project is implemented hastily. Even the detailed analyses of such issues have not been done and those create many of the problems that have surfaced in the past.

- Poor project planning and scheduling: Unavailability of construction material(s), lack of labor supply, poor site hand-over, lack of utility relocation, etc. results in a time extension, price escalation and leads to project delay.

- Improper site management: Due to lack of knowledge, skill, and capable human resources and transfer of human resources from one to another contractor hampers the project. Equipment supply, fuel supply, electricity supply, even the lack of financial resources management causes a delay in many of the projects.

\section{Conclusion}

This research finds a total of 56 various causes for delays in the construction of bridges under the "design and Build model" in Nepal through both literature re- 
views and a Questionnaire survey of three main different stakeholder groups of respondents who are currently involved in the construction of bridges through Bridge Construction Project. The eight most important causes identified during this study are Lack of stakeholder analysis, Poor portfolio management, Lack of inadequate pre-execution planning and improper time management, Lack of site management, Inadequate budget allocation and delay in payment, Lack of provision of reward and penalty, Lack of detailed survey, improper soil exploration and preparation of report without in-depth study, Contractor's excessive workload.

\section{Recommendation}

The government should expand its institution(s) according to the increased number and size of the project and the number of workers and management skills need to be enhanced on time. Compared to the number and size of the project, the construction industry should also have to strengthen its partnership with technicians and consultants. Ignoring these factors may ultimately lead to delays in various projects. The cost, quality, and schedule of the bridge construction projects can be maintained once the problem of unnecessary delay is resolved-thereby the competency of the construction industry in Nepal will be improved.

\section{Conflicts of Interest}

The authors declare no conflicts of interest regarding the publication of this paper.

\section{References}

Abdullah, M. R., Rahman, I. A., \& Azis, A. A. A. (2010). Causes of Delay in MARA Management Procurement Construction Projects. Journal of Surveying, Construction and Property, 1, 123-138. https://doi.org/10.22452/jscp.vol1no1.6

Ahmad, Z. B., Anigbogu, N. A., \& Molwus, J. J. (2018). Peculiarities of Road Projects' Cost Overruns. International Journal of Scientific \& Engineering Research, 9, 121-124.

Al-Hazim, N., Salem, Z. A., \& Ahmad, H. (2017). Delay and Cost Overrun in Infrastructure Projects in Jordan. Procedia Engineering, 182, 18-24.

https://doi.org/10.1016/j.proeng.2017.03.105

Alzara, M., Kashiwagi, J., Kashiwagi, D., \& Al-tassan, A. (2016). Using PIPS to Minimize Causes of Delay in Saudi Arabian Construction Projects: University Case Study. Procedia Engineering, 145, 932-939. https://doi.org/10.1016/j.proeng.2016.04.121

Bista, S. B., \& Dahal, R. K. (2018). Assessment of Low Bidding in Bridge Construction with Special Reference to Nepal. International Journal of Research Granthaalayah, 6, 71-80.

Gidado, K., \& Niazai, G. (2012). Causes of Project Delay in the Construction Industry in Afghanistan. In EPPM 2012 Conference Papers (pp. 63-74). Brighton, UK: University of Brighton. https://doi.org/10.32738/CEPPM.201209.0007

Gluszak, M., \& Lesniak, A. (2015). Construction Delays in Client Opinion-Multivariate Statistical Analysis. Procedia Engineering, 123, 182-189.

https://doi.org/10.1016/j.proeng.2015.10.075 
Hasan, R., Suliman, S., \& Al Malki, Y. (2014). An Investigation into the Delays in Road Projects in Bahrain. International Journal of Engineering Science, 2, 38-47.

Haseeb, M., Lu, X., Bibi, A, Dyian, M. U., \& Rabbani, W. (2011). Problems of Projects and Effects of Delay in the Construction Industry of Pakistan. Australian Journal of Business and Management Research, 1, 41-50.

Honrao, Y., \& Desai, D. B. (2015). Study of Delay in Execution of Infrastructure Projects. International Journal of Scientific and Research Publications, 5, 1-8.

Hossen, M. M., Kang, S., \& Kim, J. (2015). Construction Schedule Delay Risk Assessment by Using Combined AHP-RII Methodology for an International NPP Project. Nuclear Engineering and Technology, 47, 362-379. https://doi.org/10.1016/j.net.2014.12.019

Hytiris, N., Stott, R., \& McInnes, K. (2014). The Importance of Site Investigation in the Construction Industry: A Lesson to Be Taught to Every Graduate Civil and Structural Engineer. World Transactions on Engineering and Technology Education, 12, 414-419.

Islam, M. S., \& Trigunarsyah, B. (2017). Construction Delays in Developing Countries: A Review. KICEM Journal of Construction Engineering and Project Management, 7, 1-12. https://doi.org/10.6106/JCEPM.2017.3.30.001

Karunakaran, S., Malek, M. A., \& Ramli, M. Z. (2019). Causes of Delay in Construction of Highway Projects. A Review. International Journal of Civil Engineering and Technology, 10, 2374-2386.

Kazaz, A., Ulubeyli, S., \& Tuncbilekli, N. A. (2012). Causes of Delay in Construction Projects in Turkey. Journal of Civil Engineering and Management, 18, 426-435. https://doi.org/10.3846/13923730.2012.698913

Lokhandwala, H., \& Bhatt, R. (2015). Identification of Causes of Delay for Industrial Construction Projects in Indian Context. Journal of International Academic Research for Multidisciplinary, 2, 379-387.

Pourrostam, T., \& Ismail, A. (2011). Significant Factors Causing and Effects of Delay in Iranian Construction Projects. Australian Journal of Basic and Applied Science, 5, 450-456.

Seboru, M. A. (2015). An Investigation into Factors Causing Delays in Road Construction Projects in Kenya. American Journal of Civil Engineering, 3, 51-63. https://doi.org/10.11648/j.ajce.20150303.11

Shah, K. J., \& Apte, M. R. (2015). Causes of Delay in Construction of Bridge Girder. IOSR Journal of Mechanical and Civil Engineering, 12, 8-12.

Suwal, A., \& Shrestha, S. (2016). Causes of Delays of Motorable Bridge Construction under Postal Highway Projects, Department of Roads. Journal of Advanced College of Engineering and Management, 2, 85-92. https://doi.org/10.3126/jacem.v2i0.16101 


\section{Appendix 1: Data Regarding Agreement Data, Intended Completion Period, Completion} Progress/Date

\begin{tabular}{|c|c|c|c|c|}
\hline Contract No: & Name of Project: & $\begin{array}{l}\text { Agreement } \\
\text { Date }\end{array}$ & $\begin{array}{c}\text { Intended } \\
\text { Completion Period }\end{array}$ & $\begin{array}{l}\text { Completion } \\
\text { Date/progress }\end{array}$ \\
\hline BP-DB-070/71-02 & $\begin{array}{c}\text { Design \& Build of Bheri Bridge along } \\
\text { Ghumi-Patihalna-Chowr Road, Mahelkuna }\end{array}$ & $2 / 30 / 2071$ & $\begin{array}{l}36 \text { months from } \\
\text { Contract Agreement }\end{array}$ & 2074-02-29 \\
\hline BP-DB-068/69-06 & $\begin{array}{l}\text { Design \& Build of Babai bridge, } \\
\text { at Lathuwaghat-in Bardiya District }\end{array}$ & $3 / 20 / 2069$ & $2075-06-11$ & 2075-06-11 \\
\hline PCU-DB-WR-071/72-19 & $\begin{array}{l}\text { Design and Build of Babai Nadi } \\
\text { Bridge Matera Bhojpur, Dang }\end{array}$ & $3 / 25 / 2072$ & $\begin{array}{l}36 \text { months from } \\
\text { Contract Agreement }\end{array}$ & 2076-04-10 \\
\hline PCU-DB-WR-071/72-27 & $\begin{array}{l}\text { Design and Build of Gowar khola Bridge, } \\
\text { Pukar pasal (Tarigaun VDC) to } \\
\text { Lauhara (Manpur VDC), Dang }\end{array}$ & $3 / 30 / 2072$ & $\begin{array}{l}36 \text { months from } \\
\text { Contract Agreement }\end{array}$ & 2074-03-29 \\
\hline PCU-DB-WR-071/72-32 & $\begin{array}{c}\text { Design and Build of Patukhola Bridge, } \\
\text { Sukaura, Tulsipur MP to Hekuli } \\
\text { VDC-9 Sukadewa Dang }\end{array}$ & $3 / 29 / 2072$ & $\begin{array}{l}36 \text { months from } \\
\text { Contract Agreement }\end{array}$ & $2075-06-28$ \\
\hline BBPCU-DB-3371574-072/73-20 & $\begin{array}{l}\text { Design \& Build of Daduwa } \\
\text { Khola Bridge, Dhadwar, Bardiya }\end{array}$ & $3 / 29 / 2073$ & $\begin{array}{l}34 \text { months from } \\
\text { Contract Agreement }\end{array}$ & $2075-06-28$ \\
\hline BBPCU-DB-3371574-072/73-22 & $\begin{array}{l}\text { Design and Build of Two Bridges } 1 . \\
\text { Rapti Bridge Connecting Sisniya VDC-2 } \\
\text { \& Gobadiya VDC-6, Mahadeva, } \\
\text { Dang \& 2. Rapti Bridge, Jahare } \\
\text { Connecting Satbariya VDC and Rajapur }\end{array}$ & $3 / 28 / 2073$ & $\begin{array}{l}48 \text { months from } \\
\text { Contract Agreement }\end{array}$ & $90 \%$ progress \\
\hline BBPCU-DB-3371574-072/73-23 & $\begin{array}{l}\text { Design and Build of Bridge of Two Bridges } \\
\text { 1) Babai Nadi Bridge, Connecting Loha } \\
\text { Dabara and Dawangpur, Dang \& } \\
\text { 2) Babai Nadi Bridge, Goltakuri ko } \\
\text { Baki ra Hekuli VDC ko Baibang bich ma }\end{array}$ & $3 / 30 / 2073$ & $\begin{array}{l}33 \text { months from } \\
\text { Contract Agreement }\end{array}$ & $70 \%$ work progress \\
\hline BBPCU-DB-3371574-072/73-37 & $\begin{array}{c}\text { Design and Build of Rapti Khola Bridge, } \\
\text { Hasnapur chowk, Satbariya-1 \& Chappa, } \\
\text { Bela-5, Dang }\end{array}$ & $3 / 30 / 2073$ & $\begin{array}{l}36 \text { months from } \\
\text { Contract Agreement }\end{array}$ & $35 \%$ work progress \\
\hline BBPCU-DB-3371574-072/73-38 & $\begin{array}{l}\text { Design and Build of Babai River Bridge, } \\
\text { Matheura-6 and Dholpur-8, } \\
\text { Panchakule VDC, Dang }\end{array}$ & $3 / 30 / 2073$ & $\begin{array}{l}30 \text { months from } \\
\text { Contract Agreement }\end{array}$ & $30 \%$ work progress \\
\hline BBPCUDB3371574-073/74-003 & Bheri river bridge, Jajarkot & 2074-03-09 & $\begin{array}{l}30 \text { months from } \\
\text { contract agreement }\end{array}$ & $\begin{array}{l}\text { contract termination } \\
\text { due to disaster }\end{array}$ \\
\hline BBPCUDB3371574-073/74-004 & Bheri river bridge, Surkhet & $2074-08-27$ & $\begin{array}{l}30 \text { months from } \\
\text { contract agreement }\end{array}$ & $15 \%$ work progress \\
\hline BBPCUDB-3371574-073/74-008 & Rapti river bridge, Satbariya & $2074-08-26$ & $\begin{array}{l}48 \text { months from } \\
\text { contract agreement }\end{array}$ & $30 \%$ work progress \\
\hline BBPCUDB-3371574-073/74-009 & Rapti river bridge, Machhebash-Dampur & $2074-08-27$ & $\begin{array}{l}42 \text { months from } \\
\text { contract agreement }\end{array}$ & $65 \%$ work progress \\
\hline BBPCUDB-3371574-073/74-013 & Karnali River Bridge, Ghatgau & $2074-08-27$ & $\begin{array}{l}48 \text { months from } \\
\text { contract agreement }\end{array}$ & $20 \%$ work progress \\
\hline BBPCUDB-3371574-073/74-015 & Bheri River Bridge, Ghusenigada Ghat & $2074-08-27$ & $\begin{array}{l}42 \text { months from } \\
\text { contract agreement }\end{array}$ & $75 \%$ work progress \\
\hline BBPCUDB-3371574-073/74-018 & Rapti River Bridge, Pyuthan & 2074-03-09 & $\begin{array}{l}36 \text { months from } \\
\text { contract agreement }\end{array}$ & $25 \%$ work progress \\
\hline
\end{tabular}




\section{Continued}

BBPCUDB-3371574-073/74-019 (bridge1st)

BBPCUDB-3371574-073/74-019 (bridge2nd)

BBPCUDB-3371574-073/74-021

BBPCUDB-3371574-073/74-026

BBPCUDB-3371574-073/74-034

(Bridge 2nd)

BP-DB-070/71-01

BP-DB-068/69-05

PCU-DB-WR-071/72-20

PCU-DB-WR-071/72-26

PCU-DB-WR-071/72-33

BBPCUDB-3373204-073/74-002 (Bridge 1st)

BBPCUDB-3373204-073/74-002 (Bridge 2nd)

BBPCUDB-3373204-073/74-034 (Bridge 1st)
Babai River Bridge, Salyan

Babai River Bridge, Salyan

Doda River Bridge, Kanchanpur

Kandra River Bridge, Bijuliya

Gwar River Bridge, Dang

Design \& Build of Bheri Rimna \& Jugai Khola Bridge along Chinchu Jajarkot Road

Design \& Build of Bheri Bridge on Surkhet-Purandhara Road in Surkhet District

Design \& Build of Bridge (Goji khola and Chedegad Bridge) Chhinchu-Jajarkot Road

D\& B of Bheri bridge, Jamughat Tatapani-9 to Babiyachaur, Surkhet

Design \& Build of Karnali Bridge, Kachalighat, Kuhine, Surkhet

Man River Bridge, Gulariya

Bhada River Bridge, Gulariya

Guhar River Bridge Dang
2074-03-09

36 months from contract agreement

2074-07-22

2074-03-11

2074-03-11

$2 / 27 / 2071$

$3 / 24 / 2072$

$3 / 30 / 2072$

$3 / 28 / 2072$

2074-08-22

36 months from contract agreement

36 months from contract agreement

36 months from

Signing Contract

48 months

from Signing

Contract-ACC,

60 months from

48 months from

Signing Contract

48 months from

Signing Contract

48 months from

Signing Contract

2074-03-11
$5 \%$ work progress

$5 \%$ work progress

$60 \%$ work progress

$50 \%$ work progress

99\% work progress

2074-06-11

signing contract-SCC

2076-05-05

2076-03-24

2075-05-18

$40 \%$ work progress

$15 \%$ work progress

$30 \%$ work progress

Source: Department of Road, Bridge Branch Sector No-3 Nepalgunj, 2019. 